\title{
PETER KVATERNIK
}

\section{Duszpasterstwo rodzin wobec wyzwań wolnego czasu}

Zanim przystapiłem do rozważenia niniejszego problemu, postanowilem poszerzyć swoją wiedzę o to, jak w praktyce rodzina przeżywa i wykorzystuje wolny czas. Dlatego poprosilem o pomoc kilka mlodych, wierzących rodzin. Początkowo przystaly na moją propozycję, jednak szybko zrozumiałem, że zabieram im tylko drogocenny czas. Z każdym dniem stawało się dla mnie jasne, ze zamiast rozmawiać o wolnym czasie, wolą raczej go przeżywać.

Wydawać by sie mogło, że dyskusja na ten temat będzie bardzo łatwa. Jednak kiedy powiążemy zagadnienie wolnego czasu $z$ rodziną i będziemy chcieli zbadać ich wzajemny stosunek, staniemy przed dosyc trudnym zadaniem. Tym trudniejszym, jeśli spojrzymy na nie w aspekcie duszpastersko-teologicznym. Stwierdzimy nagle, że znaleźliśmy się jakby posrodku morza, gdzie wszystkie kierunki wydają się wlaściwe i tylko wytrawny żeglarz lub wrodzony instynkt mogą nam wskazać drogę do właściwego portu. W tej sytuacji najlepiej będzie zmierzyć szerokosć i dhugość morza oraz postuchać, z jak najbardziej wyostrzoną uwaga, skąd wieje wiatr, aby we wlaściwym momencie rozpiąc odpowiednie żagle. Spróbujemy zatem rozpoznać najpierw, jakie są wiatry współczesnego czasu i w którym kierunku popychają lódź współczesnej rodziny, by w końcu dokonać odpowiedniego wyboru żagli dla współczesnego duszpasterstwa rodzin. 


\section{Czas wolny}

Co to jest czas wolny?' ${ }^{1}$ Pozornie latwe pytanie, na które jednak znależć można wicle odpowiedzi². Do najskrajniejszych należą być może dwie następujące: czas wolny to cały ten czas, w którym nic jesteśmy w pracy, lub tylko ten czas, którym dysponujimy calkowicie swobodnic. Takicgo czasu wiçkszość ludzi, a zwlaszcza rodzin z małymi dzieci, ma niewicle.

Podręcznik pastoralno-teologiczny definiuje pojęcic czasu wolnego w następujący sposób: Czas wolny to ta przestrzeń zyciowa, w której czlowiek jest wolny od zewnętrznych obowiqzków i przymusów (praca, zarobek, awans, produktywnośc) i w ksónym, dzięki temu, dowolnie dysponuje swoim czasem i może się calkowicie poświęcić jakiejś twórczej dzialalności, bez z góry określonego zamianu $i$ celu?. Podręcznik dodaje, że dotychczas czlowiek jeszcze nigdy nie mial tyle wolnego czasu co dzisiaj oraz, że z powodu licznych obowiązków również nigdy nie potrzebowal wolnego czasu tak bardzo, jak teraz. Czas wolny nie jest przeznaczony do tego by nic nie robić, lecz w pierwszym rzędzic do tego, by rozwijać tc zdolności, którc są szczegolnie bliskie scrcu czlowieka. Aby lepicj uykurrystać wolny czas, człowick wchodzi z innymi ludźmi w różnorakic relacje. Alc zdarza siç również, że czlowick nie potrafi tego czasu odpowicdnio wykorzystywać i trwoni go lub podejmuje dodatkową pracę. Kościót w swojej misji diakonalncj stara się pomagać czlowickowi w prawidlowym wykorcystaniu czasu4.

\section{Dokumenty kościelne dotyczące czasu wolnego}

Sobór Watykański II nie omawia szerzej kwestii czasu wolnego, jednak w kilku micjscach wspomina o tym zagadnicniu. Najpierw w Konstytucji duszpasterskiej o Kościele w świecie współczesnym Gaudium et spes, w powiązaniu z opisem wielkich zmian spolecznych, z których rodzq się nowe sposoby myślenia, dziatania i spędzania wolnego czasu (KDK 54).

Kiedy mówi o nicktórych najpilniejszych zadaniach w dziedzinie kultury, omawia s7erzej problem wykorzystania czasu wolnego, w następujących slowach: Niech wolny czas będzie użyty należycie dla odpręzenia duchowego i fizycznego przez swobodne zajęcia i studia, podrózie w obce sirony (turystyka), dzięki krónym doskonali się umyst i ludzie wzbogacajq się przez wzajemne poznanie; dalej, przez ćwiczenia i pokazy sportowe, kıóre lakże w spoleczenistwie przyczyniajq się do utraymania równowagi ducha, jak i do braterskich stosunków między ludizmi wszelkiego stanu, narodowości i różnych ras

I O problemic czasu wolnego możemy dyskutować tylko na podsıwic wlasnego doswiadczcnia czasu, wedlug zasady: „Powicdz mi, jak wykorzystujesz czas, a powicm ci, kjm jesteś!". Sposóh uykorcystywania czasu wskazuje na nasz stosunck do żcia. Tylko odpowiednic współbrzmienic z rytmem czasu poawala na harmonijne urzeczywistnienic naszej egzystencji - por. O. Betz: Vom Umyang mil der Zeit. Würzburg 1996 s. 7-9.

2 Pur. V. Poloćnik: Blisč in beda prostega časa. CSS 18 (1984) 66-68.

' A. Elsüsser: Mube und Freizeit. W: Handbuch der Postoratheologi. Bd V-Lexicon. Freiburg 1972 s. 341.

- Por. Iamze. 
(KDK 61). Kicdy zaś mówi w następnym zdaniu, że chrześcijanie powinni brać udzial w imprezach kulturalnych $i$ akcjach charakserystycznych dla naszych czasów oraz przepajać je duchem czlowieczenistwa i chrześcijaństwa, zalcca przez to by chrześcijanie podejmowali również zagadnienia dotyczące wolnego czasu i nadawali mu chrzescijański wymiar.

Sobór podkreśla, że szczególnie pracownicy winni mieć możność rozwijania swoich zdolności i osobowości właśnie przez samo wykonywanie pracy. Jak z jednej strony winni oni z należytym poczuciem odpowiedzialności wkladać swój czas i sity w wykonanie pracy, tak z drugicj powinni tez wszyscy dysponować wystarczajqcym odpoczynkiem i czasem wolnym, tak aby mogli poświęcać się życiu rodzinnemu, kulturalnemu, spolecznemu i religijnemu. Przede wszysikim powinni znajdywać sposobność swobodnego rozwijania njch sit $i$ uzdolnien, kıónych być może nie mogq doskonalić w pracy zawodowej (KDK 67).

Sobór patrzy więc na czas wolny z pozytywnego punktu widzenia i w aspekcie dobra czlowieka jako takicgo, a nie tylko przez pryzmat religijnego wykorzystania tego czasu. Czas wolny jest równicż przeznaczony na życie rodzinne, kulturalne i spoleczne oraz na rozwijanic zdolności osobistych.

Problemu czasu wolnego dotyka równicż Encyklika Laborem exercens ${ }^{5}$, kiedy mówi o Świadczcniach spolecznych: Innq dziedzina świadczeń jest ta, która wiq̨że sį̨ z prawem do wypoczynku - przede wszysikim chodzi uuaj o regulamy wypoczynek tygodniony, obejmujący proynajmniej niedzielę, a oprócz tego dluższy wypoczynek, czyli tak zwany urlop raz w roku, ewentualnie kilka razy w roku przez krótsze okresy (n. 19).

Wytyczne episkopatu wloskicgo dla duszpasterstwa rodzin $n^{6}$ wspominają o problemie czasu wolnego dwukrotnie. Na czas wolny należy patrzeć w prawdziwie ludzkim i chrześcijariskim aspckcie (n. 111). Rodzicom zaleca się również, aby umożliwiali dzieciom kontakt z przyroda i wypetnianie wolnego czasu urozmaiconymi wartościami (n. 188).

O niedzicli jako dniu odpoczynku mówi papież Jan Pawel II w Liście apostolskim Dies Domini, poświęcając temu problemowi pięć punktów (64-68) ${ }^{7}$. Dla niego odpoczynek jest reczq "świętqa", pozw'ala bowiem czlowiekowi wynwać się z n'tmu ziemskich zajęć, czasem nazby! go pochlaniająych, i na nowo uświadomić sobie, że wszystko jest dzielem Bożym (n. 65). Mówi, że także w obecnej epoce histonycznej mamy obowiqzek rak dzialać, aby wszyscy mogli zaznać wolności, odpoczynku i odprężenia (n. 66). Ojcicc Święty podkreśla równicż jego znaczenie: Odpoczynek niedzielny pozwala sprowadzic do waściwych proporcji codzienne troski i zajęcia: rzeczy materialne, o które tak bardzo zabiegamy, ustępuja micjsca wartosciom duchowym; osoby, wśród klónych żyjemy, odzyskują prawdziwe oblicze, gdy się z nimi sporykamy, nawiqzzujemy spokojnq̨ rozmowę. Możemy sakże odkryć na nowo i zachwycić się glęboko pięknem przyrody, zbyt częsı niszczonym przez ludzka żądzę panowania, kıóra zwraca się przeciw samemu

'Jan Paweł Il: Encyklika Laborem exercens. Libreria Editrice Vaticana. Watykan 1981.

- Italijanska Skofovska Konferenca: Direkıorij dnızinske pasıorale. CD 73. Ljubljana 1997.

' Jan Pawel Il: List apostolski Dies Domini. Libreria Editrice Vaticana. Watykan 1998. 
czlowiekowi (n. 67). Trudno pozbyć sie wraźenia, że mów to wszytko na podstawie whasnych doswiadczen, zwlascza wtedy, kicdy stwierdza: adpocznek musi byc źódem dachowego wzbogacenia, zapewniac wieksq wothos, umoziliwiac kontemplacje i spryját braterskiej wspólnocie (n. 68).

\section{Wspötczeshe rozumienie czastr wolnego}

Od czternastut lat Instytut Badan Britsh Ametican Tobacco Germany (B.A.T.) prowadzi badania dotyczace czasu wolnego. Zapewne nie robi tego tylko z pobudek bumanistycznych, ale prede wszystkim z powodu interesów ekonomicznych. Takie podcjście moze dxisiaj przynosic ponyśne efekty ekonomicznie, a jednocześnie potwicrdza slowa Jczusa o synach tego swiata (por. Zk i6, g).

Badacze czasu wolnego konstatują, że wspólczesna kutivra doszla juí do punktu knytycznego. Akadenia Wychowania Politycznego w Tutzing (RFN) zorganizowata wiosna $2001 \mathrm{r}$. spotkanie natuowe na temat: "Demokracja a spoteczeństwo zabawy". W polowie maja tegoz roku odbyly się w Moguncji dni dyskusyje poswiecone telewizfi, pod tytulem: „TV a spoleczeństwo zabawy. W ramach spotkania probowano m.in. odpowiedzieć sobie na pytanie, cry zasada: na plyciźnte nie moźna zejśc jeszcze glçbiej, siçucta juz rzecywiście dna?

Wraz z rozprzestrzenianicn się TV rozrywka osiagneța nowa jakośc. To medium jest atraksjne tylko wtedy, kiedy dostarcza coraz to nowych bodźcow, przyennej atmosfery, lekkjch wrażeń i zadowala podstawowe uczucia. Rozrywka musi prowokowas. Jedalake nawet zabawa nic prynosi zawze pożdayych efektow, datego studia lelewizyjne usilują zmusic publicznośc do śmichu, tresując ja wczośniej do lego stopnia, że niektorzy nazy wają tych ludzi „2wierzetami pociagowymi aplauzu".

Hasło, które media probuja wtloczyc czlowiekowi, bremi nastepująco: wsystho zobaczyc, mie przegapic niczego! We wspótczesnym, ,zastraszająym tempie" (Luttwak), które przez coraz szybszy postẹp technologiczny rozklada rodzinę, media odgrywaja niezastapiona rolę. Niek tórzy nazywaja je "turboprzyspieszaczanip", poniewaz whwoJuja u ludzie wrazenie, żc nigdy nie zdąża na czas". Inni okrélaja je jako prawdziwe "Opium dla ludu"

Badace zatrudniony we wcześniej wymienionej instytucji, prof. Horst w. Opaschowski zauwaza, ze u ludzi wzrasta zapotrzebowanie na coraz to nowe programy $T V$, relacjonujące zawody sportowe i podobna plytka zawartosk, natomiast zainteresowanie wiadnomosciami i programami o zabarwicniu politycznym nie jest tak duże. Tak zwana "kultura zabawy" stale się rozrasta, "Crud się dobrze" "bawic się", staje coraz

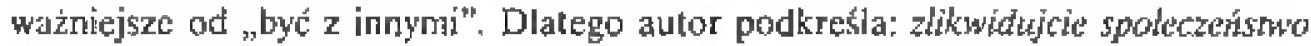
zabany, bo w preciwnym razie jakore zycia spelknie na niczym".

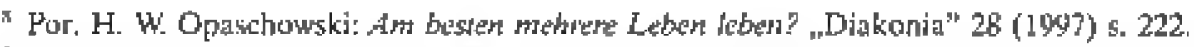

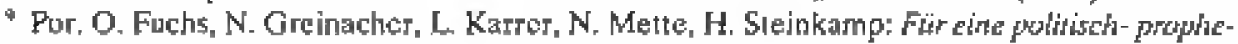

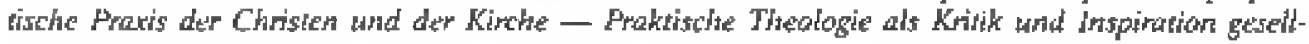
schafticher Pratis dor Kitche. Plhi 20 (200-2) 26.

It hitpt/huw.bat.de 
Siedemdzicsiąt jeden procent mlodzieży (o jedną dziesiątą więcej niż przed dziesięcioma laty) w przedziale wieku od 14 do 19 lat uważa, że najważniejszą rzeczą w życiu jest „bawić się" z przyjaciólmi lub bez nich. Ponad trzy czwarte młodych jest przekonanych, że „pomagać sobie wzajemnie" nie przynosi żadnej radosci.

Do podobnych wyników doszedl w zeszłym roku Instytut Demoskopii w Allensbach. Znaczenic motywacji socjalnych, takich jak np. milość bliźniego („być całkowicie do dyspozycji drugich, pomagać im") lub odpowiedzialność społeczna („pomagać w stworzeniu lepszego społeczeństwa"), w ostatnich latach znacznie zmalało".

Opaschowski twierdzi, że takic społeczeństwo jest tylko reakcją na stresogenne spoleczeństwo minionych lat i odpowiedzią na kryzys zatrudnienia, „turbokapitalizm” i szybkic tempo życia społeczeństwa „non stop”. Według niego społeczeństwo zabawy nie może przetrwać długo i ludzie rozdarci między społeczeństwem stresu i spoleczeństwem zabawy będą zmuszeni podjąć decyzję w kierunku jakiejś nowej formy spoleczeństwa, w którym godnym szacunku będzie ten, kto w żciu prywatnym lub zawodowym naprawdę coś zrobi.

W dzisiejszych czasach media lansują ideę, w myśl której każdy może osiągnąć to czego pragnie! Dla każdego jest przygotowany jakiš szczególny scenariusz, szczególna rola, szczególna scena! Tak rozumiane spoleczeństwo zabawy wytwarza tylko pozorny świat, skonstruowany przez media i sprzedawany ludziom jako prawda. W obecnym czasie doszliśmy już do granicy odpowiedzialności społecznej.

Dla mężczyzn zabawa oznacza przede wszystkim wolnoš́ (robić co chcesz, nie mieć obowiązków, cieszyć się swoimi sukcesami). Dla kobiet oznacza ona przede wszystkim radość życia, powiązaną z socjalnymi odczuciami (być razcm z innymi, wzajemnic się rozumieć). Dzisiejszy człowiek nie wyobraża już sobie życia bez zabawy i rozrywki. Bawić się, znaczy przedc wszystkim chwilowo nie mieć żadnych trosk, nic być pod presją czasu lub potrzeb pieniężnych i robić coś wyłącznie według własnej woli.

\section{Spoleczeństwo doznaniowe}

W ciągu ostatnich pięćdziesięciu lat jesteśmy świadkami ogromnych zmian spolecznych. W połowie zeszlego stulecia tradycja miała w życiu społecznym nadzwyczaj ważne znaczenie. Między pięćdziesiątymi a siedemdziesiątymi latami ubieglego stulecia doszło do fakıycznego przelomu kulturowego. W ciągu kolejnych dwudziestu lat różnica kulturowa jeszcze wzrosła. Po dziesięcioleciu zabawy w latach osiemdziesiątych nastąpilo, wedlug badaczy, dziesięciolecie sensu. Wszak zabawa i sens stały się jednakowo ważne. Człowiek przełomu XX i XXI wieku stara się być obecny w obu tych światach. W jego życiu religia jest tak samo ważna jak produkty firmy Adidas, Coca Cola, Levi's, McDonald's. Ludzie pragna w jednakowej mierze żyć w spoleczeństwie zabawy i w spoleczeristwie sensu. I w tej mieszance Kościola i konsumpcji, klasycznych wartości i modnych ubiorów, czują się bardzo dobrze ${ }^{12}$.

"Por. „Allensbacher Berichte" nr 5 (2001) s. 2.

12 Por. H. W. Opaschowski: Spagat zwischen Spaá und Sinn. "Frcizcit Aktucll” 150 (12.10.1999). 
Jednakże we wszystkich tych okresach było coś, co się nie zmienilo - świadomość niezależności i swobody wyboru w stosunkach między ,ja" $i$ „świat”. Dawniej świat był czymś z góry zadanym, czymś do czego należy się dostosować. Potem doszło do przewrotu. Jeśli cokolwiek jest z góry zadane, to wlaśnic ja sam! Teraz świat musi się dostosować do mnie ${ }^{13}$. Od podmiotu ukierunkowanego na świat, przeszliśmy do świata ukierunkowancgo na podmiot! Wynikiem tego jest myśl: »jeśli możliwości są skromne, należy się do nich dostosować; przeciwnic jeśli możliwości są bardzo duże trzeba je sobic podporządkować».

Ta zmiana myślenia rodzi społeczeństwo doznań i doświadczenia. W tym społeczeństwie nic górujc już myślenie wedlug alternatywy „albo-albo” lecz według alternatywy "więccj-mnicj". Taki sposób myślenia znacząco wpływa na wspólczesny, socjalny obraz świata, który zmierza ku globalizacji. Ludzie wyobrażają sobie projekt udancgo życia jako ciąg stanów psychofizycznych, którym towarzyszy odpowiednio dostosowana semantyka - czlowiek kupuje produkty i utylizuje odpadki, wybiera partnera $i$ rozchodzi się z nim, podróżuje tu i tam, trwoni i oszczędza, urządza świat wedlug własnej woli i postępuje zgodnie z zasadą, że przez dostosowanic zewnętrznego osiągnie poprawę wewnętrzncgo ${ }^{14}$.

W ten sposób powstaje nieskończona liczba form, którym rynek nadaje konkretną postać. Dochodzi do wzajemncj gry między oferującym doznania $i$ ich odbiorcą. Jednakże przynosi to również ze sobą niepewność, rozczarowania. Spoleczeństwo doznaniowe przynosi również różnorodne frustracje: nicjasności, lęk, nudę, chaos. Pomimo tego wydaje się, że wzorce myślowe o świecie ukierunkowanym na podmiot i o podmiocie ukierunkowanym na świat już się wzajemnie nie wykluczają, lecz współżyją.

Obecne stulecie będzie przede wszystkim wiekiem doznań, okresem, w którym wydarzenia będą produkowane seryjnie, a ludzie będą pod stalą presją: „Zostańcie z nami!". Uczestniczyć we wszystkim, doznać wszystkicgo, niczego nie przegapić! Zamiast spoleczeństwa informatyczncgo, które zapowiadali znawcy, przcwagę uzyska spoleczeństwo zdziccinnialc. Czlowiek będzie zmierzał ku temu, by całc jego życie stalo się wydarzeniem (event). Rodzi się pokolenie doznaniowe, które będzie musiato wybierać między konsumpcjonizmem i wyrzeczeniami. Mnicjszosć wybierze drogę spoleczeństwa postmedialnego, którc będzie szukało w życiu przede wszystkim stalości.

\section{Czas wolny w spoleczeństwie doznaniowym}

„Doznaj swego życia i wyżyj się̨!” - jest to slogan, który przeważa w zachodnich spoleczeństwach, jak również i w naszym, od co najmniej dziesięciu lat ${ }^{13}$. „Co przeżyłeś w ciągu ostatniego weekendu?" - to pytanic zadają sobie najczęściej koledzy

13 Por. G. Schulze: Gesellschaft 2000. Was wird aus der Erlebnisgesellschaft? W: Seelsarge in der Erlebnisgesellschaf. Aachen 2001 s. 22.

14 Por. tamżc, s. 23.

19 Por. B. Baumann: Freizeil und Erlebnisgesellschaft 2000. Was wird Erlebnisgesellschaft? W: Seelsorge in der Entebnisgesellschafi, dz. cyt., 4. 
i koleżanki w zakładzie pracy, uczniowie w szkole lub znajomi spotykający się przypadkiem na ulicy. Pytający oczywiście nie oczekuje, że rozmówca opisze mu zwyczajne przeżywanie wolnych dni, lecz w jego pytaniu skrywa siç ciekawość dotycząca wyjątkowych, niezwykłych przeżyć. $Z$ tego powodu człowiek musi sobie już wcześniej wymyślić taki scenariusz końca tygodnia, który dostarczy mu wystarczająco dużo materiału do odpowicdzi na takie pytania. Oznacza to, że obowiązuje zasada: „Musi zdarzyć się coś wyjątkowego, jednorazowego!" Dziś dbają o to inni: jedziesz do parku zabaw i wyjątkowych doznań ci nie braknie! Podobną rolę odgrywają kluby wakacyjne i tzw. „parki wypoczynkowe" w kempingach i miasteczkach turystycznych. Urlop jak całość musi stać się jednym samym doznaniem! Tylko wypełnione zabawą życie wydaje się być życiem wartym życia!

Aby zaspokoić oczekiwania i wymagania swoich klientów, agencje turystyczne wypracowują swoje programy na podstawie gruntownych analiz potrzeb wspólczesnego czlowieka. W ostatnich latach zachodzą znaczne zmiany sposobu wykorzystania wolnego czasu, a szczególnie urlopu. Ludzie odchodzą od przeważająccgo wcześnicj dążenia by mieć coraz więcej czasu wolnego, coraz dłuższy urlop. Zamiast tego skracają podróźc i w czasie urlopu żyją skromniej. Obowiązuje ogólna zasada: „Wszystko od razu i możliwie najtaniej!” Postępują też zgodnie z zasadą: „Lepiej krócej, lecz kilka razy w roku!" lub „Trochę na urlopic, trochę w domu!"16.

\section{Akcent na estetyce}

Dawniej wartością było to, że ktoś bardzo dlugo pracował w tym samym miejscu pracy. Dziś zmiany miejsca zatrudnicnia i stanowisk pracy, oczywiście na coraz wyższe szczeble drabiny spolecznej, są oznaką dobrze przemyślanej kariery zawodowej. Podubnic urlopowiczc nic wiążą siç z jednym miejscem, w którym spędzają urlopy, lecz chcą wybierać między różnorodnymi możliwościami. Jednak nierzadko wolność ıyboru jest dla ludzi uciążliwa, ponieważ wymaga jednacześnie wzięcia na sicbie odpowiedzialności za swoje postępowanie ${ }^{17}$.

W procesie podejmowania decyzji doszło do zmiany $z$ orientacji koncentrującej się na tym co zewnętrzne na orientację skierowaną do wewnątrz. Ważnym i niekiedy jedynym czynnikiem decydującym jest własne doznanie, dobre samopoczucie, wrażenie. Dziś jednostka pyta się, czego chce i szuka grupa, która pomoże spełnić jej oczekiwania.

$\mathrm{Z}$ wolnością $\mathrm{i}$ koniecznością wyboru oraz ukierunkowanicm do wewnątrz wiąże się również silna indywidualizacja. Każdy musi sobie sam zarysować swoje plany życiowe i każdy musi je również sam zrealizować. Wymaga to od niego wysokicgo stopnia pewności siebie, wiary w siebie i osobistej równowagi.

Do tego wszystkicgo nawiązuje eksponowanie znaczenia życiowej cstetyki. Każdy poszczególny dzień i zupełnie zwykłe rzeczy nabierają wyjątkowego znacze:?in.

${ }^{16}$ Por. Weniger, küzer und bescheidener. "Freizeit Aktucll” 152 (14.02.2000).

"B. Baumann, dz. cyt., s. 5. 


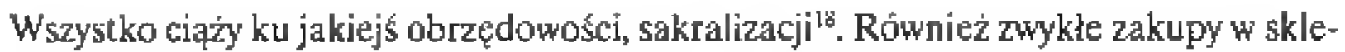
pie muszą stás się czymś pięknym. O każdej rzeczy coraz bardziej decyduje jej ksztaltt, wzór (design).

Myślenie, że w tym doznaniowym społeczeństwie wspólnota lub spotecznośc nic maja znaczenia, jest błędne. Jednak również wartośc spolecznoșci ocenia się w stosunku do przezycia, doznaria. Z tego też względu ludzie często nawiązują ze sobą kontakty ze względu na podobne przezycia zyciowe.

Społeczeństwo doznaniowe nosi w sobic zarówno zalety jak i nicbezpieczeństwa, takie jak np. to, że ktośs zmarnuje swoje życie, utraci kierunek życia, zostanie "przesączony przez towarzyskic sito". Najważniejszą wartoscią takiego spoleczeństwa jest to, że daje moźliwošc swobodnego kształtowania wlasnego życia.

Rownież w tym spolcczeństwie przyjmujeny to, co jest w nim pozytywne i szukany duszpasterskich możliwości głoszenia ewangelï, ponieważ Chrystus wyzwolił nas abysmy byli wolni (por. $J 8,36$; Ga 5,1 ).

\section{Spotecceństwo doznaniowe a wiatrat}

Jaka role odgrywa religia w spoleczeństuie doznaniowym? Niektórzy przepowiadają wierze riezbyt pewną przyszłość. "Jezus sam w dornu" - tak zatytułowat "Der Spiegel" swoj artykul w bożonarodzeniowym wydaniu w 1997 r., zamieszczając zarazem podtyul: „Wiara bez Kosciola". Wygląda na to, że Kosciót traci palmę pierwszeństwa w niektórych krajach "katolickich". Arcybiskup Fuldy Johannes Dyba powiedział w pewnym wywiadzie: Znajdujemy się w fazie lowinowego upadku. Z drugiej strony słyszyny, że zainteresowanie rcligijnosicią stale wzrasta. Dzisjejszy czlowick z jednej strony pokażuje "czcrwonq kartkę" Kościolowi, a z drugiaj strony szuka 1 kształtuje swoją wasna religijność. Zmienia się sposób poszukiwania sensu. Cztowick szaka go przede wszystkim w stosunkach życiowych.

W dzisiejszych czasach linia podziału między różymi konfesjami nte przebiega pomiędzy wiernymi wewnątrz Kościola i ludźmi poza nim. Nie tstnieje juź wielka grupa tradycyjnie wiernych wewnątrz Kosciola, a z drugiej strony grupa ludzi zupelnie innych, o ktorych nie wiadomo w co wrerzą. Sposób przeżywania wiary u poszczególnych ludzi jest bardzo róźny. Granice staly się bardzo płynne ${ }^{19}$. Nicktórzy mówį̨ o mpatchwotk- lub collage-religïności $\omega_{,}$co oznacza, że poszczególni ludzie wybieraja sobie tylko określone treści jakiejś religii.

Jeśli Kó́ciól pragnie wzbudzić zainteresowanie swoją nauką, musi wnieść do swojej trowy wiçcej realnego stosonku do życia codziennego. Nalezy polozyć most przez rów oddzielający „codzienną" i „wysoką" teologię. Wyduje stę, że trzeba będzie uznac i przyjąc jako wyzwanie fakt, że wiclu ludzi w ciągu swego zycia kilka razy

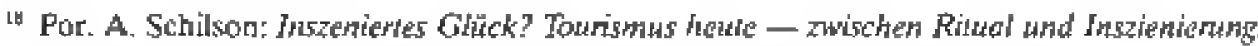

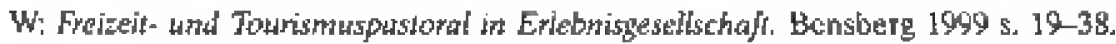

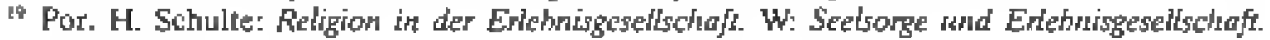
Aachen 20011 s. 15. 
zmieni swoje przekonania religijne. Kościót będzie musiat wychodzí poszukującym naprzeciw, odwiedzac w ich w miejscu zamieszkania i w pracy, tak jak to czynił Jezus (por. J 2, 1-2; Mt 4, 18).

\section{Koşciót w społeczeŕstwie doznaniowym}

$\mathrm{Ci}, \mathrm{któ} r z y$ się mocno angażują w żcie parafij i aktywnie w niej działaja, zwykle dosiuiadczaja wielu pięknych przcżý. Młodzi np. mówią, że uczestniczą w spotkaniach różnych grup, ponicważ dobrze się w nich czują, jest im proyjemrnie. Młody czlowiek pragnie równocześnie sensu i zabawy. Jednak my nfeclętnie wiążemy ze sobą te dwie sprawy i twierdzimy, że zabawa jakoś tu nie pasuje. Tak więc mamy wrażenie, ze spoleczenstwo doznaniowe i Kosiciot to dwie pary butow, a nie dwa buy z tej samej pary ${ }^{20}$.

Jesli bowiem istnicje społeczeństwo doznaniowe, to musi równiez istnieć Kościól, ktory czuje się w nim jak w domu. Ponięważ Koścíł jest czę́ńcią spoltcezeństwa, więc w xadnym wypadku nic jest prawdą, że jest on z njego wydzielony. Przeciwnie, wszystkie istotne znaki rozpoznawcze spoleczeństwa doznaniowego sa juz dzis obecne w Kościeje. Szczególnie w miastach jest rzeczą normalną, że poszczególni lućzie lub całte rodziny wybierają sobie wspólnotê, w której dobrze siç czuja i z którą się regularnie spotykają. Równiez u nas wierni wybierają między różnmi obrzędami i kosciołami.

Ludzie traktują dzisiaj Kościól, raczej jak "kiosk" niž jak "prenumeratę "w1. Ludzie nic chcą się wiązac z Kościołem na stałe, ale tylko czasowo, wyłącznie wtedy, kjedy czują, że tego potrzebują. Różnorodnof́c ofert, wynika nie tylko z rywalizacji miçdzy różnymi wyznániami i sektami, ale jest także obecna w samym Kościele, w którym zawsze istnieje szereg różnych duchowości, a wowszych czasach również ruchów i organịacji.

Także ostatni Sobór zaprasza caly Kosció, aby staną! blisko dzisiejszego czlowie$\mathrm{ka}$, mowiac: Radosc $\mathrm{i}$ nadzieja, smulek i moga ludzi wpotczesnych, szczegolnie ubogich

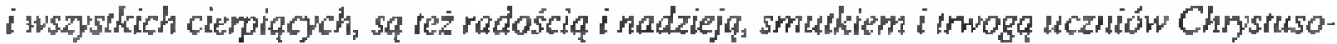
wych (KDK 1). Koscíł musi więc zachować przede wszystkim postawę diakonalną, musi zblizyc się do ludzi wtedy, kiedy cierpią, á tákże whedy, kiedy się weselą.

Kościót moze przeciwstawić estetyzacji zycia oodzjennego jego uduchowicnic (spirytualizację). Musi pokazywać obecność Boga w raeczach i traktować stworzony świat jako dobry, a nie jako już z góry przeciwstawny wszystkiemu co duchowe i Boże.

Jeśli stawiamy sobie pytanie, czy społeczcristwo doznaniowe potrzebuje Kościoia, to równoczesnie winniśny jasno stwierdziç, że potzzebuje go koniecznie. Nie możemy jednak zapominac, ze rówrież Kościót potrzebuje tego spoleczeństwa. By jednak mógl on nawiązać kontakt 2 ze wspólczesnym spoteczcístwem, będzie musial ponownie odkryć swój charakter doznaniowy.

7y B. Baumann: Die EHebniggesellschaft bracht die Kirche, welleicht die Eriebnis-Kirche?t W': Seetsorge in der Erlebniggereflichafit, dz. cyt., s. 10.

21 Tamte. 


\section{Wyzwanic dla duszpasterstwa}

Dziatalność duszpasterska w naszych parafiach odbywa się w czasie, który jest dla wiernych czasem wolnym ${ }^{23}$. Oznacza to, ze jakiekolwiek duszpasterstwo jest, zo tak powiem, duszpasterstwem czası wolnego. Kierujący wspolnotami muszą się z tym faktem liezyć, by móc lepiej rozumieć 'udzi, którzy są przedmiotem pracy duszpasterskiej, jak rówrież dlatego, ze wierni są jednocześnie podmiotem pracy đuszpaslerskiej, a spoleczeństwo doznaniowe wyciska na nich istotne piętno. Duszpasterstwo powinno míce w tym wypadku taką samą tęczę barw, jaką oferują różnorodne propozycje wykorzystania czasu wolnego.

Kościół może wybierać różne opcje. Może spoleczeństwo doznaniowe odrzucać, zupelnie się mu podporzadkowá́ lub się a nim twórczo zmierzyc. Stanąc krytycznie twarzą w twarz ze wspólczesnym zjawiskiem społeczeńsiwa doznaniowego jest najtrudniejsza moźliwością. Oznacza to bowiem, żc Kościbl musi zgodzić się na wplyw i inspirację ze strony tego społeczenstwa, a jednocześnie musi zachowac wobec nicgo krytyczny dystans. Chodzi o to, żeby Kofciobl, w swiclle Soboru Watykaŕskiego II, zobaczyl w tym spoleczentstwie „znaki czasu".

Czas wolny predstawia znaczne wyzwanie również dla samego duszpastersiwa. Albowicrn często dochodzi do zbyt wielkjego podziah na duszpasterstwo terytorialne i specjalistyczne. W duszpasterstwie czasu wolnego te dwie dziedziny nie tylko się spotykają, ale wręce się wzajemnie przeplatają.

\section{Konfrontacja z proyszościa}

Wraz z przyjęciem zachodniego modelu życia, konieczne jest jednoczesne przyjęcie zachodnich warlości. Nicmoźliwe jest cakkowite oddzielenic migracji ludzi od migracji wartoșct. Po prostu nie można się temu skutecznie i trwale przeciwstawić. Więkscych sukcesów można oczekiwać, jeśli Kosciót jest swiadomy tego wplywu i odkrywa (ponownie) w ewangelii wartósci, które pozwalają równieź „prozachodnioncmu" czlowiekowi znaležc przestrzenic, w których będzje mogg się osobiście spotkać Jczussem Chrystusem i wybrac Go.

Cechą charakterystyczną zachodniego społeczeństwa jest swiadomośc prawa do osobistego \$rczęścia i prawa do ksztaltowania wlasnego kanonu wartości. Wszystko ulega globalizacji i staje się ruchome: ludzic, gospodarka, przedsiębiorstwa, pieniądze i wartosci. Globalne dobra stwarzaja globalne style zycia, a globalne rynki pociągają za sobą globalne wartosci. Dzisiaj częste preprowadzki świadczą o czyjejs nowoczesności. Ludzic nowocześni maja zwyczaj powtarzac: kwithieny tam, gdzie jestesny zasaldzeni". Mhodzi mówią: "One world - one love parade."

Nie ma już tylko jednej jedynej instancji moralnej, która by się troszczyła o przekazywanie systemu wartosci nowym pokoleniom. Rodzice przenoszą odpowicdzial-

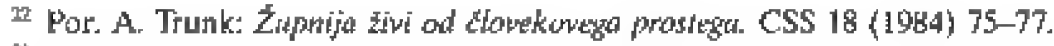

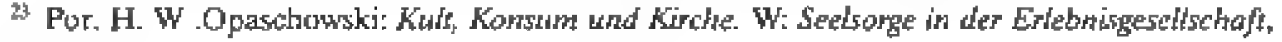
dz. cyt.. 5. 34. 
ność za wychowanie na szkołę, a ta czuje się przeciążona i przekazuje odpowiedzialnośc, jak palcczkę sztafety, dalej - mediom (81\% nauczycieli jest przekonanych, że najwiçkszy wpływ na wychowanie mają media). Z tego powodu ludzie jako konsumenci, wyborcy i w ogóle, stają się całkowicie nieprzewidywalni, a przez to również spontaniczni, clastyczni i mobilni. Podporządkowują się tylko własnym, chwilowym odczuciom i opinii publicznej. Również w przypadku kwestii moralnych „żeglują" wśród niczliczonych możliwości.

Szczególnie mlodzi uciekają z jednej strony od nakazanych związków, z drugiej zaś strony tęsknią za nowymi powiązaniami, unikają obowiązków społecznych i szukają własnych, obowiązujących zasad życiowych. Najogólniejszą i najbardziej respektowaną zasadą jest pragmatyzm i wiązanie się tylko na krótki okres czasu. Co trzeci młody czlowiek jest przekonany, że sam musi ksztaltować koncepcję swojego życia i znaleźć jego sens. Ich sloganem jest: „Daj mi korzenie, bo ich nie mam”. O pewność, jaką dawniej dawały czlowickowi wiara i Kościól, dba dzisiaj „przemysl doznaniowy" (wielki spcktakl jako wspólczesna forma pielgrzymowania) ${ }^{34}$.

Czy Kościól udziela dzisiaj właściwych odpowiedzi? Na Zachodzie Kościól podejmuje śmielsze próby przemawiania do wspólczesnego czlowieka w odpowiadający mu sposób ${ }^{25}$. Współczesnemu czlowiekowi trzeba przede wszystkim pomagać w odkrywaniu nowych „święlych obszarów”, kıóre są zgodnc z jego codzicnnymi obszarami, w których czuje się dobrze i swojsko. Rozdżwięk między życiem codziennym i wiarą stanowi dla chrzescijanina najwiçksze niebezpieczeństwo. Nie stawia siç cukru obok kawy czy herbaty, lecz wsypuje się go do nich, bo dopiero wtedy stają siç one słodkie i smaczne. Podobnie jest z naszą wiarą ${ }^{20}$. Nalcży odkrywać Boga równicż w tych miejscach, które zwykle wydają siç nam się nicgodne Jego obecności. Również w twarzach dzisiejszych ludzi, za okienkami różnych urzędów, w pogawędce sąsiadów, między wersami czasopism i w poczekalniach przychodni. Po prostu — dzisiejszy czlowick potrzebuje wzorców „codziennej mistyki”!

\section{Rodzina}

Sobór nie daje definicji rodziny, jcdnak opisuje jej znaczenie i posłannictwo dla drugich. Tak więc rodzina chrześcijańska powinna odknwac wszystkim żywq obecnośc Odkupiciela w świecie i prawdziwy charakter Kościola, i 10 zarówno poprzez milość malicriską, wielkoduszne prayjmowanie polomstwa. jednosć i wiernosk, jak również przez przepojone milościq wzajemne wspóldzialanie wszystkich czlonkow rodziny (KDK 48). Również my pragniemy w tych naszych rozważaniach patrzeć na rodzinę w aspekcie

34 Por. H. W. Opaschowski, dz. cyt., s. 35.

${ }^{25}$ Por. K. Dökler: Projekt "24 Stunden offene Kirche"; B. Baumann: Erlebnisroüume im Kirchenraum - der Christuspavillon auf der EXPO 2000, P. Wirges: Die Bibel für die Hosentasche w'szystkic pozycje W: Seelsorge in der Entebnisgesellschaft, dz. cyt., s. 45-64.

Por. C. Winkler: Allagsorre - heilige One?! W: Seelsorge in der Enlebnisyesellschaft, dz. cyl., s. 66. 
pogtębiania, przepojonego miłoscią, wzajemnego wspóldziałania wszystkicn jej członków, jej stosunku do innych rodzin i do calego swiata.

Rodzina w czasach dziniejszych znajduje się pod wohywem rozleghych, glebokich iszbkich premian spotecznych $i$ kulturowych. Wiele rodzin preżwa ten stan reczy, dochowtjac wieności tym wartosciom, klóre stanowia fundament instytucji rodzinnej. Inne stanţty niepewne i zagubione wobec swych zadan, a nawet niekiedy zwatpiy i niemal zarracily swiadomose ostatecznego znaczenia i prawdy zycia mabenskiego i rodzinntgo - tymi słowami obecny papież rozpoczyna swoją Adhortację apostolską poświęconą rodzinie?27. Trochę dalej dodaje: Kosciót chcqc spetnić swojq poshuge musi dofozyc starm, aby poznać sloswhi, w któnch urzeczywisinia się dzis matzenssiwo i rodzina (FC 4).

Bez wąlpienja do poznania warunkow zyciowych wspólczesnej rodziny konieczne jest rớwnież poznanie wszystkiego, co jest związane z jej czasem wolnym 1 jego wyk

\section{Mlodzitż - ciągle jesżcze dziecko swych czasów}

Niektórzy nazywają młode pokolenie „pokoleniem @”, wszak w 2001 roku komputer znaczy dla niego więcej niż książka. Tylko pięć lat wstecz było wśród nich cztery razy więcej korzystających z ksiąiki niz z komputera. To oczywiscie nie oznacza, że spadal wśród aich procent ezytających książki, ale to, że bardzo warasta wykorzystanie komputera. Komputer nie wpiera ksiazzki, ale ja uzupełnia. Szperanie winternecie będzie się nadal szerzyfo, nie powodując przy tym spadku atrakcyności książki.

Badacze twierdzą, że "pokolente Qو" jest ciagle pod „napięciem", ponieważ ogląda tclowizję rie nniej niż inni, oprócz tego pozwala sobie na oglądanie fllmón video, słuchanic plyt kompaktowych i kasel muzycznych, a jeơnozześnie czyta tyle ile wszyscy pozostali. Dla niego "kasa czasowa jest tak samo ważna jak "kasa pieniężna”. Kieruje się ono zasadą: "Zrobíc więcej w tym samym czasie”! Dia nicgo nic jest ważne: "Co wybrać?", ale "Co wybrać najpierw?". Zapowiada się druga rewolucja medialna, która przyniesie całe mnóstwo możliwości medialnych (telewizja kablowa, satelitarna, prywalne stacje nadawcze, video, komputer, internet), a czasu do dyspozycji będzie coraz mniej, dlatego dojdzie do ostrej walki o odbiorcę, który staje się coraz bardziej wybredny i napięty $y^{25}$.

Amerykańscy specjalisei komputerowi zapowiadali, że ,się komputerowa pożre telewizję". Dzjejc się wręcz odwrotnie. Zainteresowanie telewizją w żadnym wypadku nie slabnie, a wręcz wzrasta. Zapowiedź: "PC zamiast TV" nie zdołala się urzecrywistnjé. Dla „pokolenia @” siec elektroniczna jest tylko jeszcze jednym, dodatkowym kanałen medialnym, łączącym ze swiatern. Tak więc funkcjonuje cos innego: , Obok TV jeszcze PC". Nie jest jednak wykluczone, że - jak mówi Bill Gates "W jakimś nowym pokoleniu" będzie inaczej.

27 Por. Jan Pawitł I]: Adhortacja apostolska Familiars comsomio. Librcria Editrcie Varicana. Watykar 1981 ต. 1

In For. H. W. Opaschuwski: Am berfen mehrere Leben leben?, dz. cyt., s. 223. 
Mlodzi podkreślają prawo do whasnej "architckt try" swojej wiary i nie przyjmuja jej jako czegoś określonego "z góry" lub ,z zewnątrz" ją obowiązki szkolne. Jednakże powodem dystansu wobec uczestnictwa we wspólnocie jest nie tylko brak czasu, ale coraz powszechniejsze zamykanie się w sferze whasnej prywalnosci. Daje to im, przynajmniej na jakis czas, poczucie samowystarczalności. Z tego też powodu nie odczuwają większej potrzeby uczestniczenia w spotkaniach grup Jeligijnych. Najlepiej czują się w kręgur swoich przyjaciót lub w swojej rodzinie ${ }^{30}$.

Mlodzi ostwadczają, że wspólczesne propozycje przeżywanta czasu wolnego ich nie zadowalają. Prawdopodobnie duszpasterstwo mlodzjezy powinno skie tować swoje zainteresowania w stronę pedagogiki doznaniowej $\mathrm{i}$ w stronę muzyki $\mathbf{i}^{31}$. Aby to zaś urzeczywistnie nic potrzeba środków bogatych, ale przede wszystkirn ludzi z inicjatywą i z odpowiednim przygotowaniem.

\section{Stare wartosci wracają}

Najnowsze badania (2001 r.) wykazują, że dzisiejszy czlowick zmienia stosunek do tych wartości, które stanowią fundanent zycia rodzinnego ${ }^{52}$. Rośnie pragnienie pokoju i bczpieczéstwa. Coraz więcej ludzi zaczyna ponownie doceniać rodzinę i jej ukryte życie. Zajmowanie się rodziną staje się centralną Iroską zycia. Tak nyśli ponad polowa pylanych. Coraz większe znaczenie zyskują zajęcia domowe, praca w ogrodzie lub umiejętnosé utrzymania domu.

Ludzie pragna wyjaśnić swój stosunek do świata i wyruszyć na poszukiwanie pokoju wewnętrznego (Opaschowski). Wzrasta zainteresowanie rozmowami w kręgu osobistym o ważych kwestiach zyciowych. Ku temu skłania się mlodsze pokolenie (w wicku 14-29 lat). Zamiast powicrzchownøści dzisiejsi ludzie pragną̧ więcej powagi; batdziej pragną̧ pokoju niż przedsiębiorczości.

W miodym pokolenin rośnie wrażliwość na tradycyjue wartoścł. Łatwiej przyjmują wartości, które przynoszą więcej obowiązów i wymagają większej akceptacji ze strony innych (posłuszenstwo, wypełnianie powinności, uprzejmosc, starannos $\mathcal{c}$ ). Traca natomiast popularnosc takie postawy, jak kontestacja, towarzyskie rozluźnicnic czy uliczna wulgarnosć.

Mlode pokolenie pragnie żye w równowadze. Stikes $i$ zadowolenie z zycia the pradstawiajq już zadrej sprzecznosci, a wręc traca swoje wzajemnie whkluczajg̨ce sie znaczenie (Opaschowski). Równowaga między celami materialnymi i niematerialnymi wymaga zrównoważonej etyki. Wypełnienie powinności jest dla nich wažnicjsze niż spontanicznośc, a uprzejmośc staje się czyms ważnym.

Por. N. Metes: Whe Jugendliche Kirche efahren, "Diakonia" 28 (1997) g. 264.

刃o Por. H. Högl: Jugendliche und Freizeil. "Diakonia" 28 (1997) 5. 264.

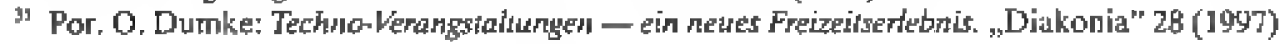
5. 251.

${ }^{3}$ Por. hitpithww bat.de 
Młode pokolenie nie zyje już w cieniu wydarzeń 1968 roku. Nie musza niczego kontestować, dlatego szukaja odpowiedniego stosunku między starymi i nowymi watrtościami. Chca zrównowazyc trzy zwlaszcza rzeczy: sukces, zadowolenie i ukierunkowanie prospoleczne. Co prawda nadal przeważa wśród nich postawa odrzucania formalnych związków malźcńskich i posiadania dzieci, jednak można juz w tym względzie zaobserwowác pewne zmiany. Dotychczas przeważaili wšród mlodych tzw. „hcgoiści" (hedonišci + egoišci). Najważnjejsi byli przyjaciele, sport, hobby i podróże.

Jeszcze w 1995 r. niektórzy zapowiadali, żc podobnie jak w preszłości Niemcy zallatla swastyka, lak obecnie swiat zaleje znak Coca Coli i że tam, gdzie kiedyś komunizm mial prawie kultowe oblicze, jego miejsce zajmie McDonald's lub Sony, że będzie się można "zaopatrywać w miłosté przez gniazdko elektryczne" i wypehniać zycie towrtrant $z$ pólek handlowych. Dzistaj widoczne są wyraźne zmiany prowadzące do podkreślania roli trwalości, stałości i istoty życia. Wzrasta też zainteresowarjie kwestiumi wiary, Religie zastępeze staja siè mniej atrakcyjne.

Filozof Jürgen Habermas, odbierajac w paździenniku w kościcle św. Paula we Frankfurcie nad Menem nagrodę pokojową, powiedzial, że po wydarzeniach, jakie mialy miejsce 11 września w Nowym Jorku, we wnętra Hudzkości drgneta strnua religijhra. Tak więc na przyszlosé zarysowuje się nowy "kanon wartosci" "ktory zapowiada pożegnanic z okresem indywidualnej egzystencji jako "układanki" i przesuniepcie w kierunku okresı wspónego planowania i budowy zycia.

\section{Codzienne probleny}

Wykazalismy juz, ze ludzie pragną gromadzić dobra nie tylko z powodu nich samych, ale chodzi. im także o ich uzytkowanie, które dostarcza przeżć. Możeny tu mówic o dżytkowntctwie zwróconym do wnętra (Knobloch). Miatoby ono dawac wiçcej pewności samego siebie, swojej egzystencji i życia. Ponjeważ ludzie doznają viebic coraz barłziej subiektywnie, dochodzi do już wcześniej wspornnianej "estetyzacji" życia, która wywoluje dzisiaj tak bardzo dostrzeganą doałośc o wasne cialợ.

Równicż w tym fakcic możemy wiđzieć chęć zadosćuczynienia za wszystkie uciążliwosci na jakie jest wystawione nasze cialo w zyciu codziennym. DIatego dzisiaj kwitną róne gabinety odnuwy biologicznej i sitownie (w Niemezech jest już ich obecnie okoto dwa i pół miliona). Wydaje się, że ze względu na wszystkie nichygody i wyobcowanie zwiazane ze zwyczajowym tempem zycia, czlowiek szuka sękompensaty waśnie w pielęgnacji swojego ciala. Stąd teź bicrze się diácenic do osiagnięcia szczupłej sylwetkj przez kutacje odchudzające, a z drugiej strony tak duzy popyt na specjaly kuliname i sprzedizż coraz to nowych ksiąźek kucharskich.

\section{Walkia o czas wolny}

Od czasu zakończenia ostatniej wojry wśród ludzi przeważa mniemanie, że najbardziej pozytywiym typem czlowieka jest "typ robotnika", klóry jest do skrajno-

33 Por. A. Sverc: Ceniti do, kar madi zivijo. CSS 35 (2001) 11-12, 210. 
s’ci zaangażowany w czynną pracę ${ }^{\mu}$. Począwszy od lat siedemdziesiątych odczuwalne jest coraz większe niezadowolenie $z$ takiego rozumienia czlowieka ${ }^{35}$. Wiedza pedagogična ponownie uświadamia sobic, że już szkola musi uczyé dzieci, jak prawidłowo korzystać ze swojego czasu wolnego. Nauka religii ma przy tym ważną misję do spelnienia.

Czlowiek musi się ponownie uczyć jak żyć, również wtedy, kiedy nic pracuje. Mówimy o „pedagogice czasu wolnego" ". Obok pytania: „1lc czasu czlowick zużywa na pracę?”, nalcży zawsze stawiać pytanie: „Ile czlowick potrzebuje czasu wolnego?”. Kościól musi brać udzial w tej dyskusji. Nie dlatego, że chce wytargować w niej jak najwięcej dla siebie, ale z powodu troski i miłości do człowieka, który potrzebuje tego czasu do zdrowego i szczęsliwego życia. Poza tym chodzi tu zawsze o pytania dotyczącc calej spoleczności. Wlaśnie w oparciu o wyniki tej dyskusji będzie możliwe ksztattowanie dobrej jakości życia parafialnego.

Kościół jest powołany do tego, żeby wspólkształtowal nową „kulturę czasu wolnego"37. Oznacza to, że poswięcamy sobic wzajemnic więcej czasu, że potrafimy wziąc sobie czas na świętowanie i zabawę, a także dla budowania większej solidarność między pokoleniami. Parafie powinny być miejscem, w kıórym jest wystarczająco dużo czasu i możliwości medytacji, șwiętowania i obrzędów, a zwłaszcza miejscem „wtajemniczenia w sens zbierania się wspólnoty". Powinna się ukształtować, dostosowana do potrzeb ubecnego czasu, "duchowośc czasu wolncgo”.

Również pod tym względem, duszpasterstwo musi mieć przed oczyma dobro ogólne czlowieka, a nie tylko cele koscielne. Ludzic będą sluchali, jeśli będziemy wychodzili $z$ ich potrzeb i razem $z$ nimi rozwiązywali ich codzienne problemy. Znaczy 10, że poświęcimy się przede wszystkim ich osamotnieniu i zagubieniu w masowości. Nic powinniśmy ludzi pouczaćc ${ }^{3 * 6}$ czy tylko zaspokajać ich potrzeby, lecz powinniśmy im stwarzać możliwość mówienia o ich problemach (w tcologii feministycznej używa się wyrażenia "hearing to spcak"). Kościół musi pokazać, że chodzi mu przede wszystkim o jakość życia, gdyż tylko ona umożliwia szczęśliwe życie, które otwiera drzwi do wiecznego szczęścia.

\section{Więccj zabawy!}

Jesienią 1959 r. znany tcolog Karl Rahner odwiedzil, wraz z Heinzem Schusterem i Herbertem Vorgrimlerem, Helmuta Erhatera w jego rodzinnych stronach, w Tyrolu. Tam przygotowywali znany „Lexikon für Theologie und Kirche”. Ciotka Erhatera miala w pobliżu kawiarnię, w której Rahner pierwsży raz zobaczyl grającą szafę. Byl nią zafascynowany. Dlugo wrzucał do niej szylingi i wybieral rózinc utwory,

* Por. J. Pieper: Muße und Kull. München 1965 s. 47.

"Już w czasach Arystotelesa czas byl uważany za „punkt, wokót którego wszystko sį̣ kręci".

to Por. M. Blasberg-Kuhnke: Die Wiedergewinnung der Muße. „Diakonia” 28 (1997) s. 235.

"Por. tamże, s. 237.

3w Karl Rahner lubil z ıcgo powodu uzywać wyrazu ,indukowac". My\$l tę przytacza S. Knobloch: Frei-Zeichen. Anfordenungen an eine Zeilzgemäße Freizeilpastoral. W: Freizeit- und Tourismuspastoral in Encbnisgesellschaft. Bensberg 1999 s. 16. 
by móc jak na najlepiej zrozumieć jej działanie. „Prawdziwy „homo ludens” mówi Erharter, kiedy opisuje to wydarzenie ${ }^{39}$.

Czlowiek nie jest stworzony tylko do pracy, lccz również do zabawy. Filozof kultury Huizinga opisuje zabawę jako dobrowolne działanie lub zajmowanie się (czymś), które toczy się w określonym czasie i miejscu, jednak niekoniecznie według surowych zasad. Jej cel jest zawarty w niej samcj. Towarzyszy jej uczucie napięcia i radości oraz świadomości, żc dzieje się coś innego niż w zwykłym życiu ${ }^{40}$. Już sama mowa ludzka, cała dzialalnośc kulturalna i cala praca mają charakter zabawy. Dlatego też jesteśmy zawsze także "ludźmi zabawy”.

Jeśli chcemy więc umieścić w życiu czas wolny, to musimy przystać na elementy zabawy w naszym życiu". Tylko w ten sposób jesteśmy zdolni do prawdziwego przeżywania świętowania i wiclbicnia Boga (por. Prz 8, 30). Kościót musi stwarzać warunki dla przyjaz.nych $i$ radosnych oraz nie stroniących od wspólncj zabawy stosunków między poszczególnymi członkami rodziny. Pomocą w tym względzie mogą służyć odkrycia pedagogiki doznaniowej (równicż „outdoor-pedagogika”) ${ }^{42}$. O tym, że ta pedagogika jest równicż u nas znana i znalazla swoje miejsce, świadczy także istnienie Towarzystwa pedagogiki doznaniowej w Lublanie i kongres, który odbył się w Zreèah ${ }^{43}$.

\section{Rodzina i urlop}

Słowo "urlop" oznacza to, że jesteśmy w tym czasie wolni. Musimy jednak postawić sobic pytanic - „od czego" i „dla czego" jesteśmy wolni. Wolni od nacisku codziennych obowiązków, stresu, zawodu, rodziny? Wolni dla własnej twórczości i zaradności? Od odpowiedzi na te pytania zależy również kształt duszpastcrstwa czasu wolncgo, ponicważ uzależnione jest ono zwlaszcza od nastroju urlopowicza" . Wspomniclišmy już, że zamiast "piçknych tygodni w roku", dzisiaj stają się interesujące "najlepsze dni w roku".

Ludzie pragna, aby czas urlopu wprawil ich w dobry humor, przynióst im szczęście i dobre samopoczucie. Te dni muszą jak najbardziej kontrastować z pozostałymi dniami roku! Oczekiwania ksztaltują się wedlug ustalonych wyobrażeń tego, co przynosi dobry humor, szczęście i dobre samopoczucie. Są to wyobrażenia o zdrowym i autonomicznym świecie. Dlatego też prospekty turystyczne są pełne takich wyrażeń jak: „fascynujące”, ,jednorazowe”, „niezapomniane”. (Amsterdam jest np. „stolica inspiracji”, Sankt Petersburg "miastem snów”, itd.).

Co możc zrobić w tym przypadku duszpasterstwo czasu wolnego? Będzie nieskutečnc, jeśli będzie chcialo za wszelką cenę burzyć ten wyimaginowany świat i wal-

"Por. H. Erharter: llomo ludens. „Diakonia" 28 (1997) s. 222.

* Por. J. Huizinga: Homo ludens. Hamburg 1956.

41 Por. C. Sorč: Krščanswo - vera veselija. CSS 18 (1984) 71-73.

"Por. J. Zigenspeck: Was ist - woher kommt die Ertebnispadagogik. W: Seelsorge in der Eitebnisgesellschaft. dz. cyt., s. 8.

"3 Por. Dušan Kulovec: Dotivljajska pedugogika. „Vzgoja” nr 12 (2001) s. 47-50.

« Por. S. Knobloch, dz. cyt., s. 9. 
czyć przeciwko nicmu. Trzeba będzie się wpisać w to, czego ludzie oczekują od urlopu i co są w stanie wtedy przyjąć.

Ich pragnienic zdrowego świata jest pewnego rodzaju kompensacją za wszystkie problemy życiowe, wszystkic przeciwności, lekceważenia, rozczarowania i spory. Nie nalcży odbierać ludziom złudzeń, żc tylko na urlopie nie ma miejsca dla łez, sporów i kłopotów, przecież sami w tym czasie również tego doświadczają.

Urlop stał się dla ludzi pewnego rodzaju symbolem religijnym, szczególnie w powiązaniu $z$ wyobrażeniem o zdrowym życiu. Stał się prawie kategorią religijną. Należy mówić ludziom o codziennych problemach i szukać lepszych rozwiązań, poniewaź ich codziennosć jest tą płodną zicmią, na której kielkują i rosną pragnicnia zdrowego swiata podczas urlopu"s.

Jeśli chodzi o uczęszczanie do kościoła w okresie urlopowym, to obraz nie jest tak zły, jak by się to mogło wydawać na pierwszy rzut oka. Badania przeprowadzone w ciągu kilku ostatnich lat wykazują, że gdzieniegdzic $28 \%$ katolików chodzi do kościoła w czasie urlopu. Jest to $w$ każdym bądź razie więccj niż $w$ ich rodzimych parafiach. Wśród osób uczestniczących we mszy w okresie urlopowym, aż $8 \%$ nie deklaruje żadnej przynależności religijnej, co jednak nie oznacza, że są niewierzący ${ }^{46}$.

\section{Koniec tygodnia czy weekend"}

Z prawie dziesięcioletnim opóźnieniem w stosunku do Europy Zachodnicj stają się u nas aktualne pytania, dotyczące czasu otwarcia sklepów oraz pracy sprzedawczyń i sprzedawców również w niedzielc ${ }^{47}$. W Niemczech i Austrii Kościól stanął zdecydowanie w obronic niedzielnego odpoczynku.

W naszych dyskusjach dotyczących kwestii niedzielnego odpoczynku, popelniamy wielki bląd podkreślając, że nicdziela interesuje nas tylko jako dzień służący uczestnictwu we mszy. Niedzjeli musimy nadać z jednej strony odpowiednią wartość, z drugiej musimy ją rozpatrywać tylko w kontekście całego końca tygodnia, który tworzą, oprócz niedzieli, również piątek po pohudniu i sobota. Trzeba bowiem wiedzieć, że dla współczesnego czlowieka nicdziela jest nie tylko końcem tygodnia, lecz również końcem „końca tygodnia” (weekendu), którego środek stanowi sobota ${ }^{4 k}$.

Kościól nie powinien czuć się upoważniony do rozwiązywania tylko problemu niedzieli, ale całego końca tygodnia ${ }^{49}$. Jest to nie tylko czas na spelnienie "obowiązku niedzielnego", lecz także czas na solidarnośc. W nawiązaniu do dziesięciu przykazań Bożych (por. Wj 34, 21), należy patrzeć na odpoczynek w aspekcie jego powiązania $z$ pracą, bo przecież są one między sobą komplementarne i tylko prawidłowe zrozumienie odpoczynku pozwala na prawidłowe zrozumienie pracyso.

is Por. S. Knubloch, dz. cyt., s. 13.

4 Por. http://www.kath.de/kasdbk

"Por. R. Spaemann: Der Anschlag auf den Sonntag. "Diakonia" 21 (1990) s. S-12.

"Por. W. Zauner: Die Zwillinge, w „Diakonia” 21 (1990) s. 41.

4" Por. K. Lang: Gefährdung von Wochenende und Sonniag. "Diakonia" 21 (1990) s. 36.

so Por. N. Mette: Sonniag ohne Sonntag? "Diakonia” 21 (1990) s. 41. 
Koniec tygodnia odgrywa ważną rolę społeczną; jest on przecieź również czasern spotkań towarzyskich i budowania wżjemnych więzi. W tym czasie nie tylko obchodżi siç rór̉ne świçta osobiste lub rodzinne, lecz takżc organizuje liczne imprezy sportowe, polityczre i kulturalne, jak rốwniez liczne spotkania ludzi na tothic proyrody i wycieckki. Również coraz więcej koscielnych imprez odbywa się w czasie kofica tygolsia.

\section{Nindzicla jakit czas walny}

Dia chrześcijanina nicdziela pozostaje dniem Pańskim, „małą Wielkanocą" đnicm świętowania zmartwychwstania Jczusa (por. J 20, 11-18). Ponieważ jest to "dzién prze7naczory dla Pana", jego centraltym wydarzeniem jest spotkante z Bogiem oraz braćmi i siostrami w wicrze podczas mszy świętej. Jednocześnie jest to dzień odpoczynku (por. Rdz 2, 2-3) i spotkań z intnymi ludźmi, zwłaszeza z chorymi, opuszwzonymi i starymi.

Nie można preoczyć došwiadczenia Starego Testancntu, w którym Izraelici otrzynywali mannç (por. Wj 16,21-30) takize w siódmym dniu, mimo że nic wymagato to szczególnego trudu. Bóg dal im preez to jasny znak, że zycie jest nie tylko owocem ich starafi, Jecz przede wszystkim Jego darem ${ }^{\text {st. }}$.

Niedziela jest dnicm wolrym od pracy i przez to stanowi wielkie wparcie dla życia. Albowiem wolnosté od pracy nie oznacza wyłącznie leniuchowania, ale çynne poszukwanie swojego micjsca w şwiecie i poszukiwanie sensu zycia ${ }^{52}$. Niedzielny ubiór, niedziclny obiad, niedzielne przebywanie na lonie przyrody, niedzielna msza — wsrystko to sklada się w jedną calośc: swiętowanie ${ }^{55}$. Jeśli mówimy o kryzysje niedzicli, musimy \$zukać jego przyczyn przede wszystkim w naszym stosunku do Boga, we wspólnocie wiernych i w Kosciele jako lakim s. Z Zerspeltywy historycznej widziñy, że Koḱciót pryyczynil się w żnacznym stopniu do urzeczywistnienia wspólczesnych standardow praw czlowieka dotyczących czasu wolnego ${ }^{55}$. Dotyccy to szczcgótnie niedzieli.

Jedinym z podstawowych konflik tów w dzisiejszych czasach wydajc się bye to, ze dzisicjszy cztowiek traktuje uczestnictwo we mszy niedzielnej jako jedną z form "wykorzystania czasu wolncgo", tynczasem Kościót mówi o tym jako o, ,obowiązku niedzielnym"n Jeśli zatem obowiązek, to dla czlowicka oznacza on zamach na jego czas woltty precd którym broni się w ten sposób, że często po prostu tego kościelnego przykizania nie shucha i przestaje uczęszczaé na mszę. Uważa bowiem, że stanowi ona zbytric "zagrozenic" dla jego planów zwązanych z wykorzystaniem czasu wolnego.

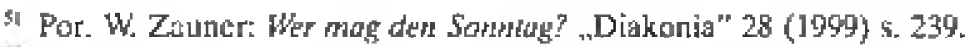

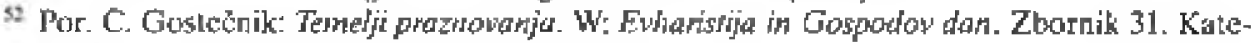
hetskega tedna. Ljubljatra 200J s. \$1-53.

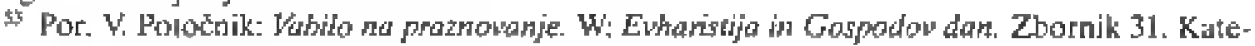
hustskega tednat. L.jubljana 2001 s. 24-36.

s Por. M. Albus: Wochestende - kein Sorntog "Diakonia" 21 (1990) s. 42-47.

55. Por. Jal Pawet Il: List apastolski Dies Dortini, nr 64-68. 


\section{Duszpasterstwo rodzin w przyszłości}

Planując duszpasterstwo rodzin musimy wychodzic z faktu, że idealna rodzina nigdy nic istniala. Dlatego jakakolwiek nostalgia za przeszlością utrudnia tylko zmiany strukluralne, którym jest poddana dzisiejsza rodzina, mówi Tamara Hareven z Uniwersytetu w Delaware. Dzisiejsza rodzina, z powodu znacznych zmian uwarunkowań, w których żyje i działa, musi się zmieniać i dlatego pozorny rozpad niektórych wcześniejszych form życia rodzinnego nie oznacza jeszcze rozkładu rodziny jako takiej.

Za punkt wyjścia powinniśmy brać fakt, że to najpierw wspólnota powinna pomagać rodzinic, a nie odwrotnie. Pomoc rodzin wspólnocic ma drugorzçdne znaczenie. Zadaniem Kościoła jest pomoc rodzinom w takim ksztaltowaniu życia rodzinncgo, by stało się ono „domowym Kościołem”s".

Każda diecczja powinna mieć stały urząd do spraw rodziny, który by skupiał dubrą ekipę specjalistów i pracowników duszpasterskich z parafii. Urząd powinien stwarzać warunki dla skutecznego duszpasterstwa czasu wolnego dla rodzin i z rodzinami.

Zainteresowanie spotkaniami w grupach, w dotychczasowej postaci, mocno spada. Powinniśmy wlożyć wicle wysiłku w przygotowanie piçknych, rodzinnych mszy, które trzeba łączyć z mniejszymi uroczystościami. Powinniśmy szukać możliwości okresowych, wspólnych pobytów rodzin i okazjonalnych, twórczych „warsztatów rodzinnych". Nalcżaloby rozwijać wrażliwość na potrzcbę wzajemncj pomocy i praygotować propozycje konkretnych form pomocy, np. wzajemnej pomocy rodzin w opicce nad wlasnymi dziećmi tak, że na zmianę, jedna rodzina opiekuje się przez określony czas dziećmi z kilku innych rodzin. W ten sposób ich rodzice mają wolny czas na umacnianie więzi malżeńskich.

Jednak przede wszystkim powinniśmy się poświęcać wewnçtrznemu, duchowemu wzmacnianiu członków rodziny, wprowadzając chociaż trochę rodzinncj modlitwy i rodzinnych obrzędów. Konieczne będzie oferowanic propozycji rodzinnych nabożeństw, w których uczestniczą wszyscy członkowie rodziny ${ }^{57}$.

Wspólczesny model życia naszych wiernych woła również o inne, nowe propozycje, które Kościól powinien zalecać lub sam je realizować. Można do nich zaliczyć np. coroczne organizowanie dnia parafii, domy przeznaczone nic tylko do celów rekolckcyjnych, alc również do prowadzenia róźnych form towarzyskiego spędzania czasu wolnego, organizowanie wycieczek ná łono przyrody, wspólne spędzanic wakacji, wspólne obozy itp. ${ }^{58}$. Dzisicjszy Kościól możc odnieść na tym polu sukces tylko wicdy, kiedy jcgo „oferta" będzie na tyle interesująca, że przewyższy wszystkie pozostałe oferty. Sposobów przeżywania czasu wolnego jest tyle, ile jest rodzin. Niemożliwe jest zatem stworzenie wystarczającej ilości teoretycznych wzorców, aby zadowolić wszystkic gusty i życzenia.

4. Por. W. Friedberger: Gemeindearbeit in Umbnuch. Freiburg 1988 s. 72-79.

"Por. W. Unterlecher: Die Familie im Wandel. "Informationen" nr 4/2001. Klagenfurt 2001 s. 5.

* Por. H. Roch: Mit Familien unterwegs. Freizeiten erfolgreich planen und durchfuhren. Mainz 1998. 
Zadanie Kościoła w tym względzie polega na umiejętności odczytywania znaków czasu, aby potem, na podstawie dobrej znajomosci i poszanowania ant ropologii, teologicznie je uzasadníc. Jednak nie powinien on zatrzynywaé się tylko na teorij, ale winien rozwinąc przynajmnicj kilka konkretnych i wattościowych ofert dotyezacych preezywania czasu wolnego, ktore będa polwierdzaly, ze jego myślenie jest prawidlowe i możliwe do zrealizowania.

Duszpasterstwo czasu wolnego jest więc zwyklym duszpasterstwem w całym swoim zaksesic. Winno być nazmaczone i przepojone poszanowanjem prawa do czasu wolnego, które wynika z samego aktu stworzenia. Powinno też uwzględniać wielorakie możliwości i potrzeby przeżwaria czasu wolnego przez wspókczesnc, jakże zróżnicowane w swcj egzystencji rodziny, odczytują̧c problem czasu wolnego w duchu Soboru Watykańskiego ll, at więc jâko znak czasu. 